\title{
Assessment of International Consensus Group for Haematology smear review rules among patients with Plasmodium falciparum malaria in Johannesburg, South Africa
}

\begin{tabular}{|c|c|}
\hline \multicolumn{2}{|c|}{$\begin{array}{l}\text { Authors: } \\
\text { Jenifer L. Vaughan }{ }^{1,2} \\
\text { Nazeer Alli }{ }^{1,2} \\
\text { Sandra Havyarimana }{ }^{3} \\
\text { Estee Benade }^{1,2}\end{array}$} \\
\hline \multicolumn{2}{|c|}{$\begin{array}{l}\text { Affiliations: } \\
\text { 'Department of } \\
\text { Molecular Medicine and } \\
\text { Haematology, University } \\
\text { of the Witwatersrand, } \\
\text { Johannesburg, } \\
\text { Gauteng, South Africa }\end{array}$} \\
\hline $\begin{array}{l}{ }^{2} \text { Department c } \\
\text { Chris Hani Bar } \\
\text { Academic Hos } \\
\text { Johannesburg } \\
\text { South Africa }\end{array}$ & $\begin{array}{l}\text { f Haematology, } \\
\text { agwanath } \\
\text { pital, } \\
\text { Gauteng, }\end{array}$ \\
\hline \multicolumn{2}{|c|}{$\begin{array}{l}{ }^{3} \text { Excellent Medical Laboratory } \\
\text { Services, Oshakati, Oshana, } \\
\text { Namibia }\end{array}$} \\
\hline \multicolumn{2}{|c|}{$\begin{array}{l}\text { Corresponding author: } \\
\text { Jenifer Vaughan, } \\
\text { jenifer.vaughan@nhls.ac.za }\end{array}$} \\
\hline \multicolumn{2}{|c|}{$\begin{array}{l}\text { Received: } 10 \text { Nov. } 2017 \\
\text { Accepted: } 17 \text { May } 2018 \\
\text { Published: } 29 \text { Nov. } 2018\end{array}$} \\
\hline \multicolumn{2}{|c|}{$\begin{array}{l}\text { How to cite this article: } \\
\text { Vaughan JL, Alli N, } \\
\text { Havyarimana S, Benade E. } \\
\text { Assessment of International } \\
\text { Consensus Group for } \\
\text { Haematology smear review } \\
\text { rules among patients with } \\
\text { Plasmodium falciparum } \\
\text { malaria in Johannesburg, } \\
\text { South Africa. Afr J Lab Med. } \\
\text { 2018;7(1), a715. https://doi. } \\
\text { org/10.4102/ajlm.v7i1.715 }\end{array}$} \\
\hline $\begin{array}{l}\text { Copyright: } \\
\text { (C) 2018. The A } \\
\text { Licensee: AOSI } \\
\text { is licensed und } \\
\text { Creative Comn } \\
\text { Attribution Lic }\end{array}$ & $\begin{array}{l}\text { IS. This work } \\
\text { ler the } \\
\text { nons } \\
\text { ense. }\end{array}$ \\
\hline \multicolumn{2}{|l|}{ Read online: } \\
\hline 回跎品 & $\begin{array}{l}\text { Scan this QR } \\
\text { code with your } \\
\text { smart phone or } \\
\text { mobile device } \\
\text { to read online. }\end{array}$ \\
\hline
\end{tabular}

A peripheral blood smear review is a useful but labour intensive adjunct to the full blood count and differential count. In this study, we retrospectively evaluated the performance of the International Consensus Group for Haematology smear review rules for detection of malaria in 153 samples with Plasmodium falciparum parasitaemia. Review rules were triggered in 132 $(86.3 \%)$ samples, including all patients with severe malaria. Of the 21 false negative samples, $14(66.7 \%)$ had haemoglobin values $\geq 10 \mathrm{~g} / \mathrm{dl}$ and platelets $>120 \times 10^{9} / 1$.

\section{Introduction}

Malaria affects in excess of 200 million people annually, with $90 \%$ of cases occurring in Africa. ${ }^{1}$ It has a significant mortality rate, with 445000 malaria-related deaths documented by the World Health Organization in 2016. ${ }^{1}$ Its diagnosis rests on rapid diagnostic tests, which detect malaria antigen, as well as microscopic identification of parasites on thick and thin smear reviews (SR). ${ }^{1,2}$ However, a proportion of patients are diagnosed incidentally where malaria is not suspected clinically following a peripheral blood SR from a sample submitted for a routine full blood count (FBC) or differential white cell count (DWCC). As such, ensuring the maximum possible pick-up rate of malaria in samples submitted for a FBC or DWCC is a priority. However, perpheral blood SR is labour intensive and requires skilled morphologists, which are in short supply. Careful selection of samples for SR is therefore vital. This was recognised by the International Consensus Group for Haematology (ICGH), who compiled a set of evidence-based guidelines directing SR in order to facilitate detection of clinically important morphologic features while reducing the number of SR done. ${ }^{3}$ These rules have reduced SR rates in many laboratories, but adjustment is often required to accommodate for local pathology patterns, clinician preferences and resource availability. For instance, in laboratories servicing haematology-oncology centres, increased vigilance for the detection of neoplastic cells in the blood is required. Many clinical haematologists prefer manual review of all samples collected from patients known to have haematological diseases, but this is not always feasible in laboratories with staffing constraints. Laboratory-specific adjustment of the ICHG SR guidelines should therefore be undertaken where necessary, with ongoing monitoring in order to facilitate further fine-tuning of the rules and to reduce false negative rates where possible. In particular, every effort should be made to ensure that life-threatening pathologies (including malaria, haemolysis, megaloblastosis and haematologic malignancies) are not missed as a result of implementation of such rules, and where pathology has been found to have been overlooked, adjustments to the SR rules should be considered.

At the Chris Hani Baragwanath Academic Hospital National Health Laboratory Service laboratory in Johannesburg, South Africa, we validated these rules, and made necessary adjustments to accommodate local peculiarities (Table 1). For example, leukopenia is very common in our setting due to the combined effects of benign ethnic neutropenia (which affects up to $60 \%$ of black South Africans) $)^{4}$ and frequent HIV infection (> 1/3 of the FBCs processed in our laboratory are collected from HIV-positive patients). ${ }^{5}$ Consequently, the low white cell count threshold for smear review was reduced from $4 \times 10^{9} / 1$ to $2 \times 10^{9} / 1$. Other changes were made on the basis of manufacturer recommendations (such as review with an immature granulocyte count $>5 \%$ as compared to the presence of an immature granulocyte flag + ), acceptable false positive rates in our experience (such as nucleated red blood cells $>5 / 100$ white cells as opposed to the presence of a 
TABLE 2: Pertinent demographic data.

\begin{tabular}{lc}
\hline Age (years) (Median [IQR]) & $\mathbf{2 3 . 5}(\mathbf{6 . 3 - 3 2 . 0 )}$ \\
\hline Male:Female ratio & $1.52: 1$ \\
Parasitaemia (\%) (Median $[\mathrm{IQR}])$ & $2.12(0.5-3.4)$ \\
Severe malaria $(n[\%])$ & $37(24.2)$ \\
Platelets $\left(\times 10^{9} / \mathrm{I}\right)($ Median $[\mathrm{IQR}])$ & $77(54.0-115.0)$ \\
$\mathrm{Hb}(\mathrm{g} / \mathrm{dl})($ Median $[\mathrm{IQR}])$ & $10.8(7.7-12.3)$ \\
Thrombocytopenia $(n[\%]) \dagger$ & $130(85.0)$ \\
Anaemia $(n[\%]) \dagger$ & $127(83.0)$ \\
\hline
\end{tabular}

$\mathrm{Hb}$, Haemoglobin; IQR, interquartile range.

$\dagger,<150 \times 10^{9} / 1$

$\dagger,<150 \times 109 / 1$. Haemoglobin below the age-specific reference interval $(<10.5 \mathrm{~g} / \mathrm{dl}$ age 6 months- 2 years, $<10.8 \mathrm{~g} / \mathrm{dl}$ age $2-3$ years, $<11.1 \mathrm{~g} / \mathrm{dl}$ age $3-5$ years, $<10.7 \mathrm{~g} / \mathrm{dl}$ age $5-8$ years, years, $<10.8 \mathrm{~g} / \mathrm{dl}$ age $2-3$ years, $<11.1 \mathrm{~g} / \mathrm{dl}$ age $3-5$ years, $<10.7 \mathrm{~g} / \mathrm{dl}$ age
$<10.3$ age $8-13$ years, $<12.1 \mathrm{~g} / \mathrm{dl}$ adult females, $<14.3 \mathrm{~g} / \mathrm{dl}$ adult males).

TABLE 3: Parameter rules triggered among patients with malaria.

\begin{tabular}{lcc}
\hline Parameter & $\boldsymbol{n}$ & $\mathbf{\%}$ \\
\hline Platelets $<100 \times 10^{9} / \mathrm{I}$ & 105 & 68.6 \\
$\mathrm{Hb}<7 \mathrm{~g} / \mathrm{dl}$ & 24 & 15.7 \\
$\mathrm{MCV}<75 \mathrm{fl}$ & $40 \dagger$ & 26.8 \\
$\mathrm{MCV}>105 \mathrm{fl}$ & $1 \dagger$ & 0.7 \\
$\mathrm{RDW}>22 \%$ & $6 \dagger$ & 4.0 \\
Reticulocytes $>0.1 \times 10^{12} / \mathrm{I}$ & $4 \dagger$ & 40 \\
WCC $<2 \times 10^{9} / \mathrm{I}(1 \mathrm{st}$ time) & 2 & 1.3 \\
Neutrophils $<1 \times 10^{9} / \mathrm{I}$ (1st time) & $2 \dagger$ & 3.2 \\
Monocytes $>1.5 \times 10^{9} / \mathrm{I}$ (adults) OR $>3 \times 10^{9} / \mathrm{I}(<12$ years) & $3 \S$ & 4.8 \\
Lymphocytes $>5 \times 10^{9} / \mathrm{I}$ (adults) OR $>7 \times 10^{9} / \mathrm{I}(<12$ years) & 1 & 1.6 \\
\hline
\end{tabular}

$\mathrm{Hb}$, Haemoglobin; WCC, white cell count; MCV, mean cell volume; RDW, red cell

distribution width; PIt, platelets. $n$, the number of all samples with the parameter of

interest. The total number of all samples for each parameter is 153 unless indicated

otherwise in the key; \%, Percentage.

$\dagger, N=149$

$\uparrow, N=10$
$t, N=63$

,$+ N=10$
$\S, N=63$

statistically between those with and without SR rules triggered (median $1.9 \%$ vs $2.1 \% ; p=0.44$ ), and was $<0.5 \%$ in six patients. Nine $(42.9 \%)$ of the samples with no SR rules triggered a request for a DWCC, and all were the first or only sample submitted.

\section{Assessment of morphology findings}

When SR was performed, malaria parasites were missed in $13.0 \%$ of cases, predominantly when the parasitaemia was low (median parasitaemia was $0.35 \%$ in those where parasites were missed vs $3.1 \%$ in those with parasites identified). The parasite detection rate was significantly greater in patients with a parasitaemia $>0.5 \%$ as compared to those with lower parasite loads $(93.1 \%$ vs $37.5 \% ; p<0.0001)$.

\section{Discussion}

In this retrospective study assessing the performance of modified ICGH SR rules in patients with malaria, SR was prompted in $86.3 \%$ of cases. Parameter flags were triggered in all patients, the commonest being the thrombocytopenia flag which was triggered in $68.6 \%$ of cases. The false negative rate $(12.7 \%)$ was higher than that recommended by the ICGH $(<5 \%),{ }^{3}$ largely due to the presence of near normal blood counts (haemoglobin $>10 \mathrm{~g} / \mathrm{dl}$ and platelets $>120 \times 10^{9} / \mathrm{l}$ ) in $70 \%$ of patients with no SR rules violated. Analyser morphology flags were evaluated only among samples with a request for a DWCC, but these did not make a substantial contribution to increasing the SR rate, with no statistical difference between those with and without a DWCC requested (85.7\% vs $86.7 \% ; p=0.87$ ). Clearly, a proportion of cases with malaria will inevitably be missed using current SR rules. Reassuringly, SR rules were triggered in all patients with severe malaria, thus reducing the likelihood of this condition being missed when not suspected clinically. However, a substantial proportion (13.0\%) of cases were missed upon SR, most commonly in cases with very low paraistaemia $(<0.5 \%)$. This highlights the poor sensitivity of microscopy for malaria diagnosis, which is highly dependent on operator skill and further compromised by the pressures of large caseloads.? Alternate means of screening blood samples for malaria (where specific malaria testing has not been requested) would be of value. Malaria detection technologies offered by several haematology analysers are of interest in this respect, as a FBC is invariably requested in hospitalised patients with fever of uncertain origin. In Sysmex analysers, malaria suspect flags are generated on the basis of 'pseudoeosinophilia' (which detects pigment-laden granulocytes or monocytes) or abnormalities of the DWCC and reticulocyte scatterplots. The reported sensitivity of these parameters is variable $(46.2 \%-69.4 \%$ for the abnormal DIFF scattergram or pseudo-esoinophilia, ${ }^{8,9} 60 \%-97 \%$ for abnormalities of the WBC/BASO scatterplot ${ }^{10}$ and $77 \%$ for abnormalities of the reticulocyte scattergram ${ }^{10}$ ), with superior performance among patients with $P$. vivax infection. ${ }^{10,11}$ In this study, a malaria flag was not triggered by the middleware in any of the cases, most likely due to the rarity of $P$. vivax infection in Johannesburg. This mirrors the poor performance of these parameters in patients with $P$. falciparum malaria reported elsewhere ${ }^{10,11}$ and suggests that the currently available malaria-specific Sysmex flags are not of significant utility in our setting. Two algorithm-based approaches for Sysmex analysers were developed by Campuzano-Zuluaga et al. using novel and research-based parameters (such as an increase in the number of events detected in the LYMPH-y channel and the number of events within a currently unevaluated area of the WBC/BASO scatterplot [designated the WBC/BASO $\{\mathrm{III}\}$ counting area]), and showed good diagnostic accuracy $(>85 \%)$ for P. falciparum. ${ }^{10}$ The utility of one of these algorithms (the N-OD1 $1_{\mathrm{Pf}}$ model) was confirmed by Dubreuil et al., who showed a sensitivity of $77 \%$ for P. falciparum detection using this algorithm in a non-endemic area (France). ${ }^{11}$ Further assessment of such models in our setting would be of interest. Lastly, the new Sysmex $\mathrm{XN}-30$ haematology analyser has novel malaria detection technology $\mathrm{y}^{12}$ currently in the testing phase, which reportedly has a sensitivity of $98.4 \%$ for P. falciparum detection (personal communication Prof. Theresa Coetzer, Dept of Molecular Medicine and Haematology, University of the Witwatersrand, Johannesburg). The study is ongoing but preliminary results are encouraging. However, it remains to be seen whether this technology could be incorporated on existing routine haematology platforms.

Other malaria-specific testing modalities carry superior sensitivity rates to conventional microscopy, such as malaria antigen rapid detection kits and various point-of-care kits 
employing polymerase chain reaction technology (such as the Illumigene ${ }^{\circledR}$, which targets a 214-base-pair segment of a non-coding region of Plasmodium species mitochondrial DNA $^{13,14}$ and has a limit of detection for P. falciparum and P. vivax of 2 and 0.125 parasites $/ \mu \mathrm{ml}$, respectively ${ }^{15}$ ). While such detection rates are impressive, these modalities are not suitable for incidental detection of malaria, but are of primary value when malaria is suspected clinically.

Limitations of this study include the paucity of clinical information, as well as the absence of non-falciparum species among the cases included.

\section{Conclusion}

The international consensus group for haematology smear review rules have a significant false negative rate for the detection of P. falciparum malaria, but perform well in patients with severe malaria. Until more sensitive technologies for incidental malaria detection are widely available, clinical vigilance for this condition is required.

\section{Acknowledgements Competing interests}

The authors declare that they have no financial or personal relationships which may have inappropriately influenced them in writing this article.

\section{Sources of support}

None.

\section{Authors' contributions}

J.L.V. was responsible for data collection, analysis and manuscript preparation. N.A. did editorial work and provided analytical input. S.H. and E.B. were involved in data collection and provided editorial input.

\section{References}

1. World Health Organization. World malaria report 2017. Geneva: WHO; 2017. Licence: CC-BY-NC-SA 3.0 IGO.

2. Blumberg $\mathrm{LH}$. Recommendations for the treatment and prevention of malaria: Update for the 2015 season in South Africa. S Afr Med J. 2015;105(3):175-178.

3. Barnes PW, McFadden SL, Machin SJ, Simson E. The international consensus group for hematology review: Suggested criteria for action following automated CBC and WBC differential analysis. Lab Hematol. 2005;11(2):83-90. https://doi.org/ 10.1532/LH96.05019

4. Ramsuran V, Kulkarni $H$, He W, et al. Duffy-null-associated low neutrophil counts influence HIV-1 susceptibility in high-risk South African black women. Clin Infect Dis. 2011;52(10):1248-1256. https://doi.org/10.1093/cid/cir119

5. Vaughan JL, Wiggil TMI, Alli N, Hodkinson K. The prevalence of HIV seropositivity and associated cytopenias in full blood counts processed at an academic laboratory in Soweto, South Africa. S Afr Med J. 2017;107(3):264-269. https://doi. org/10.7196/SAMJ.2017.v107i3.11206

6. Severe malaria. Trop Med Int Health. 2014;19 Suppl 1:7-131. https://doi.org/ 10.1111/tmi.12313_2

7. Hanscheid T. Current strategies to avoid misdiagnosis of malaria. Clin Microbio Infect. 2003;9(6):497-504. https://doi.org/10.1046/j.1469-0691.2003.00640.x

8. Huh HJ, Oh GY, Huh JW, Chae SL. Malaria detection with the Sysmex XE-2100 hematology analyzer using pseudoeosinophilia and abnormal WBC scattergram. Ann Hematol. 2008;87(9):755-759. https://doi.org/10.1007/s00277-008-0486-8

9. Yoo JH, Song J, Lee KA, et al. Automated detection of malaria-associated pseudoeosinophilia and abnormal WBC scattergram by the Sysmex XE-2100 hematology analyzer: A clinical study with 1,801 patients and real-time quantitative PCR analysis in vivax malaria-endemic area. Am J Trop Med Hyg. 2010;82(3):412-414. https://doi.org/10.4269/ajtmh.2010.09-0560

10. Campuzano-Zuluaga G, Alvarez-Sanchez G, Escobar-Gallo GE, et al. Design of malaria diagnostic criteria for the Sysmex XE-2100 hematology analyzer. Am J Trop Med Hyg. 2010;82(3):402-411. https://doi.org/10.4269/ajtmh.2010.09-0464

11. Dubreuil P, Pihet M, Cau S, et al. Use of Sysmex XE-2100 and XE-5000 hematology analyzers for the diagnosis of malaria in a nonendemic country (France). Int J Lab Hematol. 2014;36(2):124-134. https://doi.org/10.1111/ijlh.12145

12. Hamaguchi $Y$, Yoshida T, Suzuki $Y$, et al. Overview of malaria detection technology achieved with automated hematology analyzer XN-30. Sysmex J Int. 2017;27(1):1-6.

13. Notomi T, Okayama $H$, Masubuchi $H$, et al. Loop-mediated isothermal amplification of DNA. Nucleic Acids Res. 2000;28:E63. https://doi.org/10.1093/nar/28.12.e63

14. Hopkins H, González IJ, Polley SD, et al. Highly sensitive detection of malaria parasitemia in a malaria-endemic setting: Performance of a new loop mediated isothermal amplification kit in a remote clinic in Uganda. J Infect Dis. 2013;208: 645-652. https://doi.org/10.1093/infdis/jit184

15. Lucchi NW, Gaye M, Diallo MA, et al. Evaluation of the Illumigene Malaria LAMP: A robust molecular diagnostic tool for malaria parasites. Sci Rep. 2016;6:36808. https://doi.org/10.1038/srep36808 